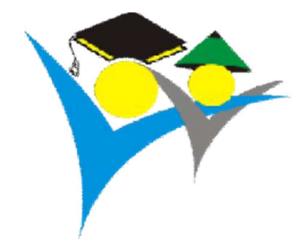

\title{
Pengenalan Dan Introduksi Teknologi Nano Pada Pengolahan Minyak Kelapa Murni Di Kecamatan Gangga
}

\author{
Tajidan Tajidan $^{1 *}$, Halil Halil ${ }^{2}$, Edy Fernandez $^{2}$, Efendy Efendy ${ }^{2}$, Sharfina Nabilah $^{2}$, \\ ${ }^{1}$ Jurusan Sosial Ekonomi Pertanian Universitas Mataram, Mataram, Indonesia; \\ ${ }^{2}$ Jurusan Sosial Ekonomi Pertanian Universitas Mataram, Mataram, Indonesia.
}

Article history

Received: 8 Juni 2021

Revised: 28 Juni 2021

Accepted: 29 Juni 2021

*Corresponding Author: Tajidan, Program Studi Agribisnis, Fakultas Pertanian Universitas Mataram, Mataram, Indonesia; Email: tajidan@unram.ac.id
Abstract: Community service is carried out because of the socio-economic conditions of the community who are not familiar with nanotechnology in the processing of virgin coconut oil (VCO) with the aim that they are familiar with, interested in its application, so as to increase the quantity and quality of VCO production and expand its marketing area. The method applied is the adult education method (andragogy). The implementation of the activities including introduction of nano technology and marketing strategies which were carried out from August to September 2020. The results of the activities shows that the processing of VCO using nano technology was a new technology that introduced to the target audience. Counseling on the introduction of nanotechnology in the processing of VCO has increased the knowledge of the participants from $52.38 \%$ to $90.48 \%$; the process of processing coconut flesh into VCO was constrained by equipment that not yet fully available in the "Andana" agro-industrial business unit as a working partner in implementing community service, including coconut milk press tool in an effort to save labor and increase the yield of coconut meat into VCO. Improving the quality of VCO is done by adding a filter layer and doing iterative filtering. There was a potential for expansion of the marketing and internal areas of the West Lombok Regency to districts within the province of West Nusa Tenggara and to provinces outside of NTB.

Keywords: quality; quantity; production; marketing; VCO

Abstrak: Pengabdian kepada masyarakat dilaksanakan karena kondisi sosial ekonomi masyarakat yang belum mengenal teknologi nano dalam proses pengolahan minyak kelapa murni (VCO) dengan tujuan agar mereka mengenal, tertarik dalam penerapannya, sehingga dapat meningkatkan kuantitas dan kualitas produksi VCO dan perluasan wilayah pemasarannya. Metode yang diterapkan adalah metode pendidikan orang dewasa (andragogy). Pelaksanaan kegiatan meliputi pengenalan teknologi nano dan strategi pemasaran yang dilaksanakan pada bulan Agustus sampai dengan bulan September 2020. Hasil pelaksanaan kegiatan menunjukkan bahwa proses pengolahan minyak kelapa murni (VCO) menggunakan teknologi nano merupakan teknologi baru yang pertama kali diperkenalkan kepada khalayak sasaran. Penyuluhan tentang pengenalan teknologi nano dalam proses pengolahan minyak kelapa murni (VCO) telah meningkatkan pengetahuan para peserta dari 52,38\% menjadi 90,48\%; proses pengolahan daging buah kelapa menjadi VCO terkendala oleh peralatan yang belum tersedia lengkap di unit bisnis agroindustri "Andana" sebagai mitra kerja dalam pelaksanaan PKM; peralatan yang sudah dilengkapi dan telah digunakan adalah alat press santan dalam upaya menghemat tenaga kerja dan peningkatan rendemen daging buah kelapa menjadi VCO. Peningkatan kualitas VCO dilakukan dengan menambah lapisan penyaring dan melakukan pengulangan penyaringan. Tersedia potensi perluasan wilayah pemasaran dan internal wilayah Kabupaten Lombok Barat ke kabupaten dalam wilayah provinsi Nusa Tenggara Barat dan ke provinsi di luar Nusa Tenggara Barat.

Kata kunci: kualitas; kuantitas; produksi; pemasaran; VCO

\section{PENDAHULUAN}

\section{A. Dasar Pertimbangan}

Potensi pertanian di Kabupaten Lombok Utara adalah perkebunan kelapa rakyat. Tanaman kelapa tumbuh subur membentang dari wilayah pesisir utara Pulau Lombok hingga perbukitan Punikan di sebelah barat dan lereng Gunung Rinjani di sebelah timur. Berdasarkan data dari Badan Pusat Statistik (BPS) Kabupaten 
Lombok Utara bahwa luas areal dan produksi perkebunan kelapa rakyat dari tahun 2016 sampai dengan tahun 2018 menunjukkan tren yang meningkat, artinya areal perkebunan kelapa semakin bertambah dari tahun ke tahun, demikian juga produksi kelapa meningkat dari 11.250,58 ton pada tahun 2016 menjadi 12.060,70 ton pada tahun 2018 (BPS, 2019).

Tabel 1.

Luas Areal dan Produksi Kelapa Kabupaten Lombok Utara

\begin{tabular}{ccc}
\hline Tahun & Luas Areal (Ha) & Produksi (ton) \\
\hline 2018 & $11,476.00$ & $12,060.70$ \\
2017 & $11,222.25$ & $11,820.70$ \\
2016 & $11,247.75$ & $11,250.58$ \\
\hline
\end{tabular}

Sumber: Kabupaten Lombok Utara Dalam Angka 2019, 2018, dan 2017

Potensi buah kelapa telah menjadi komoditas perdagangan antar pulau. Buah kelapa gelondongan diperdagangkan ke Surabaya Jawa Timur dan ke Banjarmasin Kalimantan Selatan. Buah kelapa juga diolah menjadi minyak goreng. Sejak tahun 2014 telah diperkenalkan pengolahan minyak kelapa murni (virgin coconut oil) atau minyak kelapa dara (VCO). Perkembangan sosial ekonomi masyarakat telah mengantarkan kemajuan pemanfaatan buah kelapa.

Pemanfaatan buah kelapa semakin bervariasi dan berkembang, selain diolah sebagai minuman segar, buah kelapa juga diolah sebagai koperasi, minyak goreng, dan minyak kelapa murni yang berkhasiat bagi kesehatan (Kusumaningrum, 2014; Noya, 2018; Amrinola, 2016). Pengolahan dan pemanfaatan buah kelapa mendapat dukungan langsung dari pemerintah daerah maupun dari pemerintah pusat. Penyuluhan dan pelatihan pengolahan minyak goreng dan minyak kelapa murni dilaksanakan oleh Dinas Perkebunan Provinsi Nusa Tenggara Barat bekerjasama dengan Universitas Gajah Mada. Dinas Pertanian dan Perkebunan Kabupaten Lombok Utara bekerjasama dengan Lembaga Swadaya Masyarakat (LSM) untuk memasyarakatkan teknologi pengolahan minyak kelapa murni (VCO) secara luas di masyarakat pengrajin minyak goreng (Tajidan, et al., 2019).

Dalam rangka pemanfaatan potensi perkebunan kelapa oleh Kementerian Desa, Pembangunan Desa Tertinggal dan Transmigrasi telah memberikan bantuan program Pilot Inkubasi Inovasi Desa - Pengembangan Ekonomi Lokal (PIID-PEL) berupa pembangunan rumah produksi dan gudang pengolahan kelapa menjadi minyak goreng di Desa Sokong Kabupaten Lombok Utara (Anonim (a), 2018; Anonim (b), 2018). Rumah Produksi dan Gudang VCO mulai dikerjakan pada bulan Oktober 2018. Tujuan pemberian bantuan tersebut agar produk VCO dan minyak goreng dapat dikembangkan menuju pemasaran produk berskala nasional (Anonim (c), 2018).

\section{B. Tujuan dan Manfaat Kegiatan}

1. Tujuan Kegiatan

Kegiatan pengabdian kepada masyarakat bertujuan untuk:

a. Pengenalan teknologi nano pada proses pengolahan minyak kelapa murni;

b. Penerapan teknologi nano pada proses pengolahan minyak kelapa murni;

c. Meningkatkan kuantitas dan kualitas produksi minyak kelapa murni.

2. Manfaat Kegiatan

Kegiatan pengabdian kepada masyarakat memberikan manfaat kepada kelompok masyarakat khalayak sasaran antara lain berupa:

a. Meningkatkan pengetahuan tentang teknologi nano;

b. Mengintroduksikan teknologi nano pada proses produksi minyak kelapa murni;

c. Menghasilkan benefit opportunity kepada pengolah minyak kelapa murni. 


\section{METODE}

\section{A. Tahapan Pelaksanaan}

1. Tahapan Persiapan

a. Pengorganisasian

Rapat persiapan antara tim pelaksana dengan kelompok khalayak sasaran dalam hal ini adalah melibatkan Unit Bisnis Agroindustri VCO “Andana” di Dusun Karang, Desa Gondang, Kecamatan Gangga; menjalin kerjasama dengan Pendamping UMKM Desa Bentek dalam pelaksanaan kegiatan pengabdian kepada masyarakat, membuat kesepakatan tentang pembagian tugas dan kontribusi masing-masing pihak yaitu: Tim Pelaksana, Kelompok Masyarakat yang tergabung dalam unit bisnis "Andana" dan Pendamping UMKM; dan penyusunan jadwal tentatif pelaksanaan kegiatan yang diterima oleh para stakeholders.

b. Penjajakan Kegiatan

Mempersiapkan administrasi persuratan peminjaman tempat, meubelair, sound untuk pertemuan dan pelaksanaan kegiatan (Lampiran-1); meminta dukungan fasilitas dari Kepala Desa dan pihak lain dalam mensukseskan pelaksanaan kegiatan; menyiapkan bahan-bahan kebutuhan pertemuan dan pengenalan yang meliputi Kit ATK, peralatan dan bahan-bahan yang dibutuhkan; pengangkutan bahan dan peralatan ke lokasi kegiatan dibantu oleh Pendamping UMKM dan kelompok masyarakat khalayak sasaran, serta menyiapkan form daftar hadir, evaluasi awal dan form evaluasi akhir, serta daftar penerimaan biaya transport peserta.

c. Penawaran Kerjasama

Menjajaki kerjasama dengan pemerintahan desa; melibatkan mitra kerja di antaranya dinas UKM Perindag Kabupaten Lombok Utara; melibatkan Tenaga Pendamping UMKM.

2. Tahapan Pelaksanaan

a. Evaluasi Awal

Evaluasi awal dilakukan dengan pengisian form penilaian oleh kelompok khalayak sasaran. Form disiapkan sebanyak anggota kelompok khalayak sasaran yang akan ditentukan dalam persiapan pelaksanaan.

b. Pengenalan Teknologi Nano

Penyuluhan pengenalan teknologi nano; diskusi teknologi nano; pengadaan peralatan dan bahan yang diperlukan dalam penerapan teknologi nano; pengangkutan peralatan dan bahan-bahan praktik; penempatan peralatan dan bahan-bahan yang dibutuhkan; penyetelan peralatan; penyiapan bahanbahan; praktik penerapan teknologi nano di lokasi usaha khalayak sasaran yang dihadiri oleh narasumber dan peserta khalayak sasaran.

c. Evaluasi Akhir

Evaluasi akhir dilaksanakan dengan kegiatan antara lain: penyiapan angket; penyebaran angket ke peserta; peserta diminta untuk mengisi angket evaluasi secara objektif; melakukan tabulasi hasil evaluasi; menganalisis data evaluasi; serta menyimpulkan hasil dan dampap pengabdian kepada khalayak sasaran.

\section{B. Metode Pelaksanaan}

Pengenalan dan/atau introduksi teknologi nano dilaksanakan dengan menerapkan metode pendidikan orang dewasa (andragogy), yaitu suatu metode pembebasan dengan merekonstruksi pengetahuan dan pengalaman pengusaha agroindustri minyak kelapa murni menjadi pengetahuan dan keterampilan yang berstruktur dan bermanfaat dalam memproduksi dan memasarkan produk sampingan agroindustri minyak kelapa murni (Pappas, 2015). 


\section{HASIL DAN PEMBAHASAN}

\section{A. Pelaksanaan}

1. Teknis Evaluasi Awal

Tim Pelaksana menyiapkan angket evaluasi awal dalam format kuesioner pilihan tunggal. Quiz sebanyak 10 soal yang terdiri atas 5 (lima) kelompok pertanyaan, yaitu nilai ekonomi 2 (dua) item pertanyaan, penggunaan atau pelanggan produk VCO 2 (dua) utem pertanyaan; pemasaran 2 (dua) item pertanyaan, kualitas produk VCO 2 (dua) item pertanyaan, dan teknologi nano 2 (dua) item pertanyaan. Naskah form angket diprint sebanyak 30 lembar, setiap lembar untuk satu orang peserta.

Sebelum penyajian materi, form angket diberikan kepada peserta untuk dijawab sesuai dengan pengetahuan masing-masing. Waktu yang disediakan bagi setiap peserta dalam menjawab pertanyan evaluasi sekitar 10 (sepuluh) menit, namun mereka mampu menjawab dalam waktu $5 \mathrm{sd} 7$ menit.

Form evaluasi dikumpulkan oleh tim pelaksana dan dibantu oleh Pendamping UMKM Desa Bentek (Efendy Brajamusti). Berikutnya peserta diminta untuk mengisi daftar hadir. Daftar Hadir diisi oleh peserta, narasumber, dan Pendamping UMKM yang hadir pada pelaksanaan pengabdian kepada masyarakat.

2. Proses Penyajian Materi

Kegiatan pengabdian kepada masyarakat dilaksanakan di Aula Kantor Desa Bentek. Aula merupakan bangunan menggunakan tiang baja dan rangka baja ringan dengan atap menggunakan spandek. Sebagai ruang terbuka, maka pecahannya sangat terang dan sirkulasi udara lancar. Bangunan aula merupakan bangunan tahan gempa, sehingga cukup nyaman sebagai tempat penyelenggaraan pengabdian klasikal atau tutorial.

Sebelum peserta hadir di lokasi kegiatan, tim pelaksana dibantu oleh Pendamping UMKM desa Bentek mempersiapkan pengadaan sound system, LCD Projector, kursi dan meja. Peserta dan menyajikan diatur berhadapan, sehingga membentuk kondisi seperti ruang kelas.

\section{B. Hasil Pelaksanaan}

\section{Hasil Evaluasi Awal}

Sebagai kegiatan awal dalam pelaksanaan Pengabdian Kepada Masyarakat (PKM) dilakukan tes awal untuk mengetahui sejauh mana pengetahuan peserta terhadap materi yang diserahkan. Dari hasil tes awal menunjukkan bahwa bahwa peserta memiliki cukup pengetahuan tentang Minyak Kelapa Murni (Virgin Coconut Oil).

Pengetahuan mereka terlihat dari nilai test awal di atas 50\% dari 10 pertanyaan yang diajukan. Dengan menggunakan soal metode pemilihan tunggal (one choice) memberikan gambaran bahwa peserta memiliki pengetahuan yang baik pada aspek pengguna dan kualitas VCO, namun masih rendah pada aspek pemasaran dan teknologi nano. Pengetahuan tentang teknologi nano hampir separuh dari peserta yang belum mengetahuinya.

Dengan memperhatikan hasil test awal di atas, maka tepat sekali memilih topik tentang pengenalan teknologi nano pada pengolahan minyak kelapa murni di Kecamatan Gangga Kabupaten Lombok Utara. Materi yang juga perlu disuluhkan adalah pada aspek pemasaran, terutama adalah pemilihan rantai pemasaran, perluasan wilayah pemasaran, termasuk pembentukan nilai tambah dan rantai nilai pemasaran.

2. Materi Penyuluhan

Kegiatan PKM ini melibatkan UMKM setempat yang telah berpengalaman dalam memproduksi dan memasarkan produk VCO. Pengusaha VCO diundang sebagai informan sekaligus sebagai narasumber. Sebagai narasumber dari kalangan praktisi adalah Muharar Muslim, S.Pd. yaitu pemilik (owner) Andana VCO. Selain pengusaha lokal, juga materi disampaikan oleh tim pelaksana. Adapun topik materi yang disampaikan pada kegiatan PKM meliputi Nilai Ekonomis Dalam Pengolahan Minyak Kelapa Murni (VCO); Perluasan Pangsa Pasar Minyak Kelapa Dara (VCO); Teknologi Nano pada Pengolahan Minyak Kelapa Murni (VCO); dan Peningkatan Kualitas Produk VCO. 
a. Nilai Ekonomi VCO menekankan pada marjin kontribusi dan atau nilai tambah yang dihasilkan dalam pengolahan minyak kelapa murni (VCO). Untuk menghasilkan 1 (satu) liter VCO dibutuhkan 13 butir kelapa. Harga kelapa per butir Rp 3.000, maka harga bahan baku adalah Rp 39.000, sementara harga 1 (satu) liter VCO adalah Rp50.000 sd Rp75.000,- maka nilai tambahnya berkisar antara Rp11.000 sd Rp36.000 per liter tergantung kualitas dan saluran pemasarannya. Jika diolah harga VCO meningkat antara Rp150.000 sd Rp200.000 per liter di tingkat produsen, maka dipastikan nilai tambahnya semakin besar.

Salah satu permasalahan pengembangan agroindustri VCO adalah perluasan pangsa pasar. Wilayah pemasaran yang terbatas di wilayah Kabupaten Lombok Utara mengakibatkan terhambatnya peningkatan produksi. Materi perluasan pangsa pasar VCO dimaksudkan untuk memberikan alternatif tindakan yang dapat dipertimbangkan sebagai upaya perluasan pangsa pasar. Strategi yang diterapkan dalam perluasan pangsa pasar adalah : menghasilkan produk yang berkualitas, harga yang bersaing, lokasi usaha yang strategis, dan promosi.

Keempat strategi pemasaran di atas dikenal dengan bauran pemasaran (marketing mix). Dalam praktiknya memperbanyak jaringan ke luar wilayah diantaranya dengan membentuk jaringan agen di kabupaten kota di dalam dan di luar wilayah promosi, serta bekerjasama dengan pengusaha di luar provinsi, termasuk Jawa Timur dan DI Jakarta. Pemanfaatan teknologi digital dan jaringan internet serta pemasaran on line merupakan langkah tetap dalam memperluas wilayah dan meningkatkan pangsa pasar. Proses pendidikan masyarakat khususnya calon konsumen menjadi penting, sebab VCO merupakan produk yang menawarkan peningkatan daya tahan (imun) tubuh, serta memiliki khasiat bagi pemeliharaan kesehatan tumbuh.

b. Pengenalan teknologi nano merupakan core utama dari topik PKM di Kecamatan Gangga yang dilaksanakan oleh tim dan bekerja sama dengan pengusaha VCO setempat. Teknologi Nano merupakan pengetahuan baru yang sebelumnya hampir belum dikenal luas. Teknologi ini telah diterapkan pada pengolahan minyak goreng sawit, sementara pada pengolahan VCO merupakan suatu yang baru. Selain implementasi teknologi pemancingan, sentrifugasi, dan frozen, kita kenal teknologi nano. Teknologi nano adalah menghasilkan produk berukuran partikel atau berukuran nano $(1$ nano $=$ perseribu millimeter $)$. Produk VCO yang dihasilkan adalah produk suspensi dalam bentuk gel atau bentuk cair, serta dimungkinkan dimodifikasi menjadi sublim). Prosesnya adalah melalui penghancuran bahan-bahan menjadi partikel berukuran nano tersebut. Teknis pelaksanaannya adalah melalui penggilingan atau pengadukan yang disertakan dengan penggunaan katalis.

c. Peningkatan kualitas VCO dimungkinkan melalui penyaringan yang terlampir. Sebaiknya penyaringan menggunakan kertas saring agar hasil sampingan berupa protein atau benda lainnya tidak tercampur dengan produk. Kualitas produk VCO selain ditentukan oleh kejernihannya, juga kandungan kadar air. Kadar air yang masih tinggi dapat mempercepat VCO mudah "tengik". Penurunan kadar air selain menggunakan metode gravitasi, juga dilanjutkan dengan metode "absorbsi" yaitu mengikat air menggunakan "arang aktif". Salah satu bahan arang aktif adalah arang tempurung kelapa. Tempurung kelapa dibuat menjadi arang, selanjutnya arang ditaruhkan di atas kertas saring yang diletakkan di dalam corong penyaring.

3. Pengamatan Penerapan

Pemantauan atas proses PKM dilakukan satu minggu setelah dilaksanakannya kegiatan penyuluhan. Hasil pemantauan (monitoring) menunjukkan bahwa setelah satu minggu kegiatan penyuluhan dilaksanakan belum tampak penerapan teknologi nano dalam proses pengolahan minyak kelapa murni. Alasan belum diterapkannya teknologi nano adalah belum memiliki peralatan yang dibutuhkan, serta peralatan harus steril dan bebas dari bahan-bahan lain atau bahan-bahan pencemar.

Selain itu, pemilik usaha (owner) belum yakin bahwa penerapan teknologi nano dapat meningkatkan kuantitas produksi dan / atau kualitas produk, serta dapat menaikkan harga jual. Oleh karena itu perlu dilakukan demonstrasi penggunaan teknologi nano agar dapat menyakinkan para pemilik usaha 
pengolahan kelapa menjadi minyak kelapa murni (VCO).

4. Faktor Pendorong dan Penghambat

Kegiatan Pengabdian Kepada Masyarakat (PKM) dengan menggunakan metode penyuluhan memungkinkan menyampaikan informasi dari narasumber ke audien (peserta). Menyampaikan materi dengan menggunakan metode penyuluhan atau ceramah dinilai efektif mentransfer pengetahuan (kognitif), namun untuk sampai kepada penerapan dibutuhkan metode praktikum atau eksperimen dan demonstrasi. Berikut ini adalah beberapa foto kegiatan praktik penerapan pembuatan VCO yang telah didemonstrasikan di Unit Bisnis Agroindustri “Andana” di Dusun Karang Kates Kecamatan Gondang.
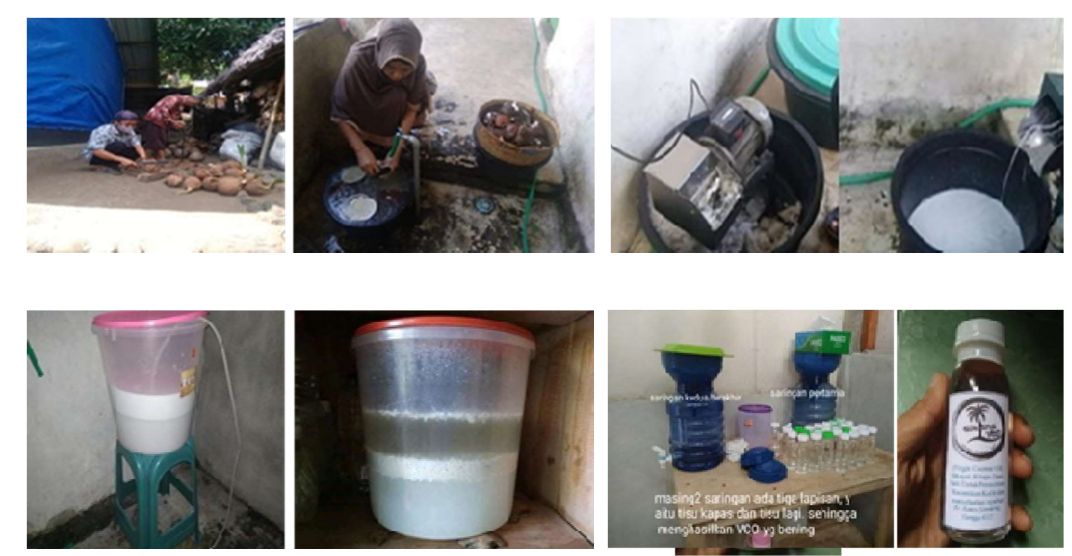

Gambar 1.

Tahapan praktik pembuatan VCO di Dusun Karang Kates Kecamatan Gangga dari mulai Pengupasan, pencucian daging buah kelapa, parutan daging buah kelapa, pengepresan santan, pemisahan air dengan blondo, hingga penyaringan dan pelabelan.

\section{Hasil Evaluasi Akhir}

Peserta yang mengikuti PKM dievaluasi sejauh mana penyerapan pengetahuan yang diperoleh selama proses pelaksanaan penyuluhan. Kegiatan penyuluhan ini dinilai efektif meningkatkan pengetahuan para peserta. Pernyataan ini didasarkan pada hasil evaluasi akhir atau hasil tes akhir yang menunjukkan adanya peningkatan pengetahuan pada semua komponen penilaian, yaitu nilai ekonomi, pengguna, pemasaran, kualitas produk dan teknologi nano.

Hasil evaluasi akhir memperlihatkan bahwa pengetahuan pada aspek pemasaran dinilaimasih rendah. Hasil ini seiring dengan kendala yang dihadapi dalam pengembangan agroindustri atau pengolahan VCO secara komersial. Peningkatan pengetahuan pemasaran ini penting untuk ditingkatkan di masa yang akan datang termasuk bagaimana praktik pemasaran dapat disimulasikan atau dipraktekkan langsung kepada para pengusaha VCO.

Dari aspek kualitas produk tampaknya sudah ada solusinya melalui introduksi teknologi, namun aspek pemasaran masih menjadi kendala terbesar, khususnya bagaimana melakukan promosi melalui proses pendidikan masyarakat agar terbiasa mengkonsumsi VCO sebagai bagian dari upaya meningkatkan imun tubuh dalam menghadapi serangan bibit penyakit, khususnya untuk mencegah timbulnya gejala penyakit Covid-19.

\section{Pembahasan}

\section{Peningkatan Pengetahuan}

Peningkatan pengetahuan tampak sekali pada semua komponen penilaian. Nilai tes awal dibandingkan dengan nilai tes akhir tampak ada peningkatan. Peningkatan terjadi pada semua komponen penilaian yaitu nilai ekonomi, pengguna, pemasaran, kualitas produk dan teknologi nano.

Peningkatan pengetahuan teknologi nano yang tampak mencolok dari 52,38 menjadi 90,48. Tampaknya pengenalan teknologi nano dalam kegiatan PKM sangat efektif mendongkrak pengetahuan bagi peserta yang hadir, merupakan peningkatan tertinggi dibandingkan dengan peningkatan pengetahuan tentang 
kualitas dan nilai ekonomi, sementara peningkatan yang terendah dijumpai pada kategori pemasaran. Hal ini konsisten dengan kondisi di lapangan yang menunjukkan bahwa kelemahan terbesar dalam pengembangan agroindustri VCO adalah pada aspek pemasaran.

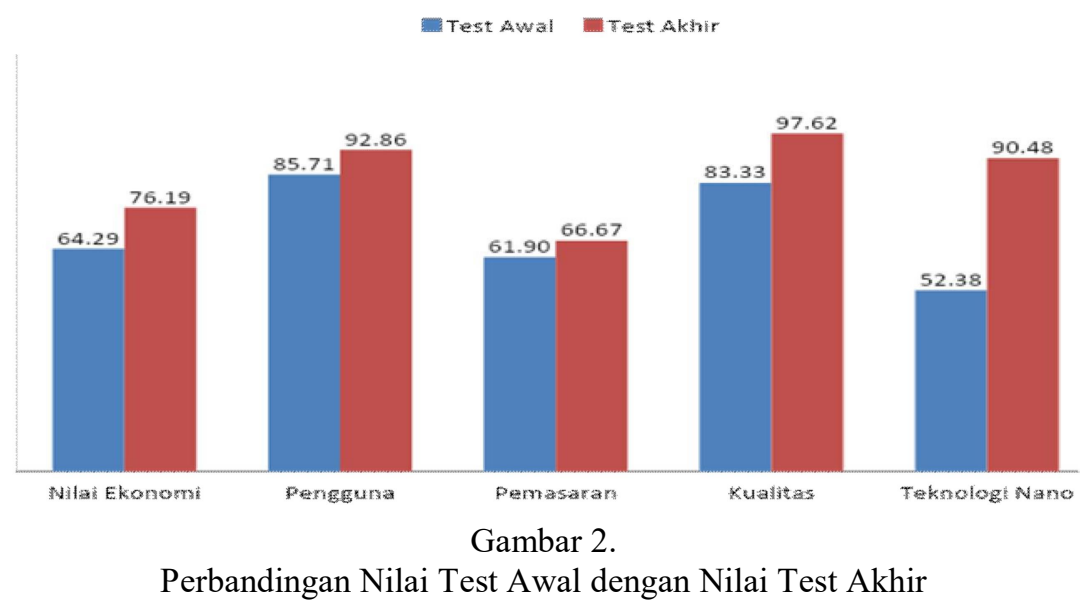

Secara umum bahwa nilai rata-rata tes akhir lebih tinggi jika dibandingkan dengan tes awal. Rata-rata nilai tes awal 69,52 meningkat pada nilai tes akhir menjadi 84,76. Dengan demikian, maka kegiatan PKM yang dilaksanakan telah meningkatkan aspek kognitif peserta, namun kelemahan dalam analisis ini adalah tidak menyorot aspek gender dari para peserta dan juga tidak mengidentifikasi latar belakang peserta.

Nilai rata-rata tes awal sebesar 69,52 artinya 69,52 persen dari jumlah peserta telah memberikan jawaban yang benar, sementara sisanya 30,48 persen memberikan jawaban yang tidak tepat atau berbeda dari kunci jawaban yang disediakan oleh tim pelaksana PKM. Sementara nilai rata-rata tes akhir sebesar 84,76 sama dengan persentase soal yang dijawab dengan benar oleh peserta. Dari 10 soal yang disediakan, jumlah soal yang mampu dijawab dengan benar sekitar 8 sampai 9 soal. Bila digunakan patokan acuan absolut, maka nilai peserta secara umum masuk dalam kategori sempurna (excellent).

2. Perbaikan Metode Produksi

Banyak metode produksi yang telah ditemukan oleh para praktisi dalam proses produksi VCO. Metode yang umum dipakai adalah:

a. Metode Pemancingan

Metode pemancingan adalah menggunakan VCO yang sudah jadi sebagai media untuk memancing VCO pada bahan setengah jadi (santan yang telah dipisahkan dengan air $=$ blondo). Perbandingan VCO dengan blondo adalah 1:8 partinya satu liter VCO dicampur merata dengan 8 liter blondo). VCO dan blondo dicampur merata dengan mengadu. Alat pengaduk yang digunakan antara lain sendok atau mixer. Khasiat VCO adalah mempercepat pembentukan VCO pada blondo, sekaligus mengikat minyak kelapa dan membentuk VCO. Hasil VCO yang diperoleh disisihkan sebanyak VCO yang digunakan sebagai pemancing. Produksi VCO adalah seluruh produksi VCO dikurang dengan volume VCO pemancingan.

b. Metode Sentrifugasi

Metode sentrifugasi menggunakan alat centrifuge. Centrifuge adalah alat elektronik yang berfungsi memisahkan minyak dari bahan-bahan padat yang ada pada blondo. Dengan memanfaatkan gaya sentrifugal, minyak yang terkandung dalam blondo akan terpisah, karena perbedaan berat jenis.

c. Metode Frozen

Metode Frozen memanfaatkan perbedaan titik beku minyak dan air. Titik beku air yang lebih rendah mengakibatkan air lebih lambat membeku daripada minyak. Bahan setengah jadi berupa blondo ditetapkan pada toples plastik. Toples plastik yang berisi blondo diletakkan di dalam baskom atau 
bak yang lebih besar. Di sisi keliling toples plastik diletakkan es batu yang telah dipecah dan diberikan tambahan garam untuk mempertahankan agar es awet dingin. Blondo diaduk agar dinginnya merata dan dibiarkan 2-3 jam sampai minyak membeku. Air dan minyak akan terpisah menjadi tiga lapisan, yaitu bagian bawah air, bagian tengah minyak, dan bagian atas blondo padat. Berikutnya dilakukan pemisahan air dari minyak dengan menggunakan gaya gravitasi, yaitu air disedot dengan pipa plastik transparan. Selanjutnya dilakukan penyaringan air diperoleh VCO yang jernih.

d. Teknologi Nano

Penggunaan teknologi nano merupakan hal baru pada pengolahan pangan, termasuk bahan pangan berupa suspensi. Minyak kelapa berbentuk suspensi, maka proses pengolahannya disesuaikan dengan bentuk bahannya. Intinya adalah VCO sudah ada dalam bahan buah kelapa. Yang perlu dilakukan adalah mengubah bahan dari bongkahan menjadi partikel berukuran nano. Prosesnya adalah melalui penggilingan daging kelapa. Daging kelapa tidak melalui proses pemarutan, namun langsung digiling menjadi partikel berukuran debu sebagaimana membuat tahu. Partikel daging kelapa dipres menggunakan alat pengepres. Alat pengepresannya menggunakan tekanan hydraulic atau menggunakan alat press sederhana menggunakan ulir seperti tampak pada gambar.

\section{Peningkatan Produksi dan Mutu Produk VCO}

Mutu produk sangat ditentukan dari bahan baku dan proses pengolahan serta pengemasannya. Bahan baku berupa daging kelapa tua yang belum tumbuh tunas dan berukuran besar, serta diperoleh dari kelapa pantai, memenuhi syarat sebagai bahan pembuatan VCO

Daging kelapa yang berkualitas menentukan kualitas dan kuantitas hasil yang diperoleh. Semakin baik kualitas daging buah kelapa, maka kualitas minyak yang dihasilkan juga semakin baik. Semakin besar dan bernas daging buah kelapa akan menghasilkan volume VCO yang semakin banyak pula.

Proses pengolahan khususnya pemarutan dan pengepresan juga berpengaruh terhadap kuantitas produk VCO yang dihasilkan. Dengan menggunakan alat pengepress dimungkinkan bahwa hampir semua minyak akan terpress keluar. Penggunaan alat press tentu akan meningkatkan rendemen buah kelapa menjadi minyak. Demikian juga mengubah daging buah kelapa menjadi bubur memungkinkan sebagian besar dari minyak dapat diekstrak, sehingga diharapkan produksi VCO dapat meningkat.

Yang tidak kalah pentingnya adalah proses penyaringan. Penyaringan merupakan rantai nilai yang menentukan kualitas produk VCO. Pada proses ini menentukan tingkat kejernihan VCO yang akan berdampak pada warna dan kebeningan produk. Oleh karena itu dalam proses penyaringan hendaknya menggunakan beberapa kali dan menggunakan bahan penyaring yang standar yaitu menggunakan kertas saring. Penggunaan tissue tidak dianjurkan, namun masih dimungkinkan menggunakan tissue dengan catatan menambah lapisan tissue hingga $3-4$ lembar serta dilengkapi dengan menggunakan kapas steril. Pengulangan penyaringan sangat dianjurkan untuk mendapatkan standar kualitas. Sebagai komponen kualitas VCO selain kejernihan, juga kadar air. Kadar air yang tinggi dapat menurunkan kualitas VCO. Langkahnya adalah ketika dilakukan penyaringan ditaruhkan arang aktif didalam corong penyaringan, sehingga air yang masih ada dalam VCO dapat terserap.

4. Pengenalan Teknologi Nano

Sebagaimana hasil evaluasi awal di atas bahwa pengetahuan tentang teknologi nano masih sangat sedikit bagi para peserta, sekaligus sebagai gambaran pengetahuan masyarakat yang masih minim tentang teknologi nano tersebut. Separuh dari para peserta belum mengenal teknologi nano, bahkan ada di antara peserta yang belum pernah mendengar teknologi nano tersebut. Sebagian peserta pernah membaca melalui media on line, namun sebatas informasi yang masih terbatas. Berbeda setelah dilakukan kegiatan PKM mengindikasikan bahwa para peserta memperoleh pengetahuan tentang teknologi nano tersebut. Hal ini ditunjukkan oleh meningkatnya pengetahuan peserta, sekitar $80-90 \%$ peserta telah mengenal teknologi nano tersebut. Peningkatan pengetahuan peserta tentang teknologi nano memberikan harapan bahwa mereka akan menginformasikan pada keluarga, teman, kenalan, dan 
masyarakat disekitar mereka, sehingga makin banyak orang yang mengenal tentang teknologi nano tersebut.

Di Indonesia sudah dirintis penerapan teknologi nano pada produk makanan antara lain pada pengolahan kulit manggis. Kulit manggis telah diekstrak untuk keperluan peningkatan kesehatan tubuh manusia melalui proses penggilingan dan menghasilkan serbuk kulit manggis. Produk lainnya adalah pengolahan berbagai jenis empun-empun untuk diekstrak kandungannya diantaranya adalah jahe yang diolah sebagai bahan pembuatan "tolak angin". Teknologi nano juga telah diterapkan pada pengolahan pulp sebagai bahan baku kertas, serta pengolahan buah sawit menjadi minyak goreng. Karena ada kesamaan antara minyak sawit dengan VCO maka memungkinkan untuk dirintis pemanfaatan teknologi nano pada pengolahan VCO melalui proses penggilingan buah kelapa menjadi bubur daging kelapa (palp kelapa) dan selanjutnya minyak kelapa diekstrak tanpa menggunakan pemanas menjadi VCO.

5. Perluasan Wilayah Pemasaran

Wilayah pemasaran produk VCO yang dihasilkan oleh para pengusaha di Kabupaten Lombok Utara masih terbatas dalam wilayah Kabupaten Lombok Utara dan beberapa kabupaten di Pulau Lombok. Peluang perluasan wilayah pemasaran adalah kabupaten / kota yang ada di Pulau Sumbawa dan di Kabupaten di wilayah Provinsi Nusa Tenggara Timur. Wilayah yang kurang perkebuan kelapanya seperti Pulau Sumbawa dan Nusa Tenggara Timur terbuka peluang sebagai perluasan wilayah pemasaran VCO. Peluang ekspor produk VCO Kabupaten Lombok Utara masih terbuka juga ke negeri jiran Malaysia dan ke Timor Leste. Permintaan ekspor ke Malaysia telah dirintis oleh Persatuan Pengusaha Wanita (PPW) dan Ikatan Pengusaha Wanita dengan target pertama 5 ton. Yang diperlukan adalah promosi akan khasiat VCO bagi pemeliharaan kesehatan masyarakat. Penggunaan berbagai media online dinilai efektif untuk menyebarluaskan informasi tentang khasiat VCO tersebut.

Dalam beberapa bulan terakhir khususnya sejak bulan Mei 2020 sampai saat laporan ini dibuat telah terjadi lonjakan permintaan VCO, karena dari hasil testimoni telah diketahui bahwa VCO dapat meningkatkan imun tubuh dalam menghadapi pandemi Covid-19

Dalam beberapa seminar juga telah dijadikan tema seminar akan khasiat VCO dalam meningkatkan imunisasi tubuh. Ada pihak yang meragukan hasiat VCO tersebut di satu sisi, namun disisi lain ada yang mempercayai bahwa asam linoleat yang terkandung dalam buah kelapa dan diekstrak menjadi VCO telah diketahui khasiatnya secara luas yaitu sebagai asam lemak tak jenuh berantai pendek yang mudah dicerna dan diolah menjadi energi dan peningkatan stamina tubuh. Pihak yang meragukan khasiat VCO sebagai fungsi peningkatan imun tubuh baru sebatas testimoni, belum dilakukan uji klinis akan khasiatnya, sehingga masih bisa diperdebatkan.

\section{KESIMPULAN DAN SARAN}

\section{Kesimpulan}

Proses pengolahan minyak kelapa murni (VCO) menggunakan teknologi nano merupakan teknologi baru yang pertama kali diperkenankan kepada khalayak sasaran dan melalui kegiatan penyuluhan dan pendampingan singkat telah meningkatkan pengetahuan para peserta dari 52,38\% menjadi 90,48\%. Proses pengolahan daging buah kelapa menjadi VCO terkendala oleh peralatan yang belum tersedia lengkap di unit bisnis agroindustri "Andana" sebagai mitra kerja dalam pelaksanaan PKM. Oleh karena itu telah diberikan bantuan dan telah digunakan sebuah alat press santan dengan harapan menghemat tenaga kerja dan peningkatan rendemen daging buah kelapa menjadi VCO.

\section{Saran}

Untuk meningkatkan pengetahuan peserta tentang teknologi nano diperlukan tambahan kegiatan praktik dan fasilitas pengalaman empiris, agar kemampuan kognitif ditingkatkan menjadi kemampuan psikomotorik. Introduksi teknologi nano tidak saja terbatas pada kalangan masyarakat namun juga diperlukan introduksi pada kalangan birokrat, sehingga secara bersama dapat membantu pengadaan peralatan yang dibutuhkan bagi kelompok pengusaha VCO di Kabupaten Lombok Utara. 


\section{Ucapan Terima Kasih}

Terima kasih disampaikan kepada Ketua Lembaga Penelitian dan Pengabdian Kepada Masyarakat, Dekan Fakultas Pertanian, Ketua Badan Pengembangan Penelitian dan Pengabdian Fakultas Pertanian Universitas Mataram yang telah memfasilitasi pembiayaan bagi terselenggaranya kegiatan pengabdian kepada masyarakat. Terima kasih disampaikan kepada Panitia Seminar Pepadu yang telah menyelenggarakan seminar, serta terima kasih pula kepada Redaktur Jurnal Siar Ilmuwan Tani yang telah bersedia menerbitkan artikel ini.

\section{Daftar Pustaka}

Anonim. 2018a. Lombok Utara Bangun Rumah Produksi dan Gudang VCO. https://kick news.today,

Anonim. 2018b. Lombok VCO Produk Unggulan Sokong. https://sokong-lombokutara.desa.id,

Anonim. 2018c. Pemda Lombok Utara Bangun Rumah Produksi VCO. https://gerbang.co.id,

Amrinola, W., 2016. Manfaat VCO Bagi Kesehatan. https://foodtech.binus.ac.id.

BPS. 2019. Kabupaten Lombok Utara Dalam Angka. Badan Pusat Statistik Kabupaten Lombok Utara.

Handoko, OT dan S. Nurfauziah. 2017 Virgin Coconut Oil, Minyak Ajaib Yang Multifungsi. https://lemonilo.com.

Karinov. 2018. Bauran Pemasaran dari 4P Menjadi 7P. (https://karinov.co.id/pengertian-bauran-pemasaran7p/

Kusumaningrum, F. Diah. 2014, Manfaat Mengkonsumsi Daging Kelapa Untuk Kesehatan Tubuh. https//: merdeka.com.

Noya, A.B. Leuan. 2018. Manfaat Buah Kelapa Untuk Kesehatan, https://alodokter.com

Tajidan, Halil, Edy Fernandez, Efendy. 2018. Pelatihan dan Pendampingan Peningkatan Nilai Tambah Produk Agroindustri Tahu di Kabupaten Lombok Utara. Lembaga Penelitian Universitas Mataram.

Tajidan, Edy Fernandez, Halil, Efendy. 2019. Pendampingan Pembiayaan Pada Pengembangan Agroindustri VCO di Desa Sokong - Tanjung. Lembaga Penelitian Universitas Mataram.

Toemon, S. 2017. Mengenal Teknologi Nano. https://bobo.hrid.id.

Wulan, R.Teja. 2016. Teknologi Nano, Penting Namun Belum Berkembang di Indonesia. https://voaindonesia.com.

Yusfi, L.A. 2019. Nano Teknologi Pertanian: Dari Pupuk Nano hingga Sensor Nano. https://warstek.com. 